\title{
Analysis of Sharia Banking Financial Fraud using Beneish Ratio and Sharia Compliance Ratio
}

\author{
Rudy Mikiyanto Kusumo ${ }^{1}$, Tarjo $^{2}$, Bambang Haryadi ${ }^{3}$, Moh. Nizarul Alim ${ }^{4}$, Prasetyono ${ }^{5}$, Rita \\ Yuliana $^{6}$, Daisar Rahman ${ }^{7}$ \\ \{rudy.kap.er@gmail.com ${ }^{1}$, tarjo@trunojoyo.ac.id ${ }^{2}$, bambang.haryadi@trunojoyo.ac.id ${ }^{3}$, \\ nizarul@trunojoyo.ac.id ${ }^{4}$, prasetyono_akt@trnojoyo.ac.id ${ }^{5}$, rita.yuliana@trunojoyo.ac.id ${ }^{6}$, \\ daisarrahman@mail.com ${ }^{7}$ \}
}

Department of Accounting, University of Trunojoyo Madura ${ }^{1,2,3,4,5,6,7}$

\begin{abstract}
The concept of Sharia is recently growing in Indonesia. It offers sharia compliance and Islamic values in company management. Therefore, the Islamic concept applied in Islamic banks is inseparable from fraud. $99 \%$ of BPR /BPRS liquidation cases are caused by fraud (Kompas, 2017).This research was descriptive. Data were taken from Financial Statements of Sharia Rural Banks (BPRS) HA on 2013 -2015. In addition, the data collection used documentation method while the analysis used Ratio Index. The classification of Sharia Rural Banks (BPRS) HA during 2013 to 2015 based on Beneish ratios revealed that, in that period, the Sharia Rural Banks (BPRS) HA were classified as a non-manipulator. Results of research indicate that these are classified as nonmanipulators, however the DSRI, AQI, SGI, DEPI and profit sharing ratios prove that there is a fraud in the financial statements. These ratios can be used as a tool to detect fraud on Sharia Banks' financial statements.
\end{abstract}

Keywords: fraud, beneish, sharia compliance

\section{Introduction}

In the past few years, the performance of the world Islamic economy shows great potential and continues to grow and it is estimated that the volume of the halal industry and global Islamic finance will grow to reach USD 6.8 Trillion (Liputan 6 2018)[1]. Sharia trends also have increasingly developed in Indonesia because the majority of the population in Indonesia is moslems. It offers sharia compliance and Islamic values in company management. Meanwhile, it also raises fraud in Sharia banks management as occurred on 2013, there were fictitious loans that were potentially harming the country by 59 billion involving 3 officials of Syariah Bank Branch of Bogor (Liputan 6 2013)[2]. The Director of IDIC Accounting and Budget Group, Suwandi, said that in general the closed banks were actually able to compete with other banks, but many frauds by their directors, commissioners, and Rural Banks causing banks to be liquidated (Finansial Bisnis 2015)[3]. In addition, based on bank liquidated data on IDIC web from January 19, 2006 to April 29, 2016, there were 1 Conventional Commercial Bank, 66 Conventional Rural Banks and 2 Sharia Rural Banks. The statistic above indicates that Sharia concept in Islamic banks is inseparable of fraud.

Fraud may not be eliminated, but it losing effects may be minimized by detecting either the fraud is occurring or has occurred as soon as possible. Beneish (1999)[4] states that variables capable of detecting earnings manipulation are Variable Days Sales in Receivable Index (DSRI), Gross Margin Index (GMI), Asset Quality Index (AQI), Sales Growth Index (SGI), Depreciation Index (DEPI), Sales General and Administrative Expenses Index (SGAI), Leverage Index (LVGI) and Total Accruals to Total Assets Index (TATA). Kaur et al (2014)[5] in their study used 5 beneish ratios, namely DSRI, GMI, AQI, SGI and DEPI variables to detect earnings management in 6 sectors in India on 2012-2013. In addition, Roxas (2011)[6] in his research indicated that the Beneish M Score Model uses 5 variables, which then resulting in more significant outcomes, by identifying $62 \%$ of companies as manipulators rather than using 8 variables, which only identifying 46 companies as manipulators. Further, Tarjo \& Herawati (2015)[7] indicate that Gross margin index of Beneish Model M Score, depreciation index, sales index and general administrative burden and all significant total accruals in detecting the financial fraud. In addition, Omar et al (2014)[8] indicated that Megan Media manipulated their income with a fictitious income of RM 198,727. Suyanto (2009)[9] who urges beneish ratio to classify Manipulator companies and manipulators indicates that Pressure Variables (Profit/ total assets) and Opportunity (Inventory/total 
assets, related party transaction and Big 4) significantly relates to fraud of financial statements. Handayani et al (2016)[10] indicates that the relationship between cash flow and profit can be used as red flags, meanwhile the correlation between receivables and income cannot be used as red flags, and the correlation between allowances for uncollectible accounts and receivables cannot be used as red flags. Therefore, Beneish Ratio has the ability to detect fraud in financial statements in non-sharia companies based on the research above.

Rahman \& Anwar (2014)[11] indicates that Management and non-management employees representing internal parties accounted for $22 \%$ of fraud parties while the rest is caused by outside factors. In addition, there is a fraud detection tool as disclosed by Najib \& Rini (2019)[12] indicating that Sharia Compliance proxied by a profit sharing ratio has a significant negative effect on fraud in the Banks, but Sharia Compliance proxied by Income Islamic Ratio and Investment Islamic Ratio does not have significant effect. Astuti et al (2019)[13] showed that the implementation of sharia corporate governance is still not able to prevent fraud in sharia banking. Based on the research above, the Beneish ratio and profit sharing ratio can be used to detect fraudulent financial statements.

In other studies about frad in islamic bank, Junita (2016)[14] indicates that financial stability pressure, proxied by Total Asset Change (ACHANGE), and external pressure proxied by the Free Cash Flow Ratio (FREEC) has a significant effect on fraudulent financial statements and can detect fraudulent financial statements, while financial targets proxied by ROA and effective monitoring as proxied by IND does not significantly affect fraudulent Sharia banking financial statements. Suryanto and Ridwansyah (2016)[15] urges that Sharia Financial Accounting Standards, Independent Sharia Council and Sharia Auditors Competency have a simultaneously effect to prevent fraud in sharia banks in Indonesia and those 3 variables Synchronization can detect occurring fraud. Fathi et al. (2017)[16] showed that significant relationship on age, gender, religiosity and position in influencing the bank employees to commit asset misappropriation in the Islamic banks. The studies above indicate the fraud perpetrators, the prevention and detection effectiveness and financial ratios of fraud detection in Sharia banks.

Based on the phenomenon/cases and research above, the researcher examines "Behind the Sharia Rural Bank (BPRS) Liquidation Process, Case Study of HA Sharia Rural Bank" using a beneish ratio as the financial statements detection of non-sharia institutions. Besides, there is also sharia compliance as a detection tool and distinguishes sharia and non-sharia institutions. $99 \%$ of BPR /BPRS liquidation cases are caused by fraud (Kompas, 2017)[17]. The researchers choose HA Sharia Rural Bank case study because it business license was revoked due to fraud. These issue becomes researcher's attention to choose the research title above. Based on the background, the research problem is:

1. Is HA Sharia Rural Bank classified as manipulator on 2013, 2014 and 2015?

2. Which variables of beneish ratio indicate a fraud?

3. Can Sharia Compliance prove there is a fraud in HA Sharia Rural Bank?

Using the research problems above, this research aims to discover a fraud as a cause upon the liquidation process at HA Sharia Rural Bank above. Therefore, this research benefits are as follows:

1. For Auditors, it can be used as a reference in detecting fraud in the Sharia Banks.

2. For Scholars, it can be used as a research reference to develop knowledge in fraud detection

\section{Literature Review}

\subsection{Sharia Compliance}

Sharia compliance is the fulfillment of all sharia principles in all activities carried out as a form of Islamic financial institutions (Usnah and Suprayogi, 2015)[18]. The MUI DSN fatwa and Indonesia Bank (BI) regulations as a measurements of compliance using sharia principles, both in products, transactions, and operations in Sharia bank.

Some provisions to be used as qualitative measures to assess sharia compliance in the Islamic financial institutions cover the followings:

1. A used contract to collect and distribute the funds according to the sharia principles and applicable sharia rules.

2. Zakat funds are calculated, paid, and managed according to the Sharia rules and principles.

3. All economic transactions and activities are reported fairly according to applicable sharia accounting standards.

4. Work environment and corporate culture according to sharia. 
5. The finance sharia businesses do not oppose sharia.

6. There is a Sharia Supervisory Board (DPS) as a sharia director upon whole operational activities of sharia bank. (Sutedi, 2009:146)[19]

\subsection{Financial Statement Fraud}

According to Association of Certified Fraud Examiners (ACFE ,2016)[20], fraud is a cheating or mistake conducted by a person or entity who knows this mistake can result in some poor benefits for the individual or other parties. it can be caused by several triggers, namely pressure, opportunity, and rationalization. (Donald R. Cressey, 1953 in Hall and Singleton, 2007:296)[21].

Association of Certified Fraud Examiners (ACFE) categorizes fraud in three groups, namely Fraudulent Financial Statements, Asset Abuse, and Corruption. Fraudulent Financial Statements is fraudulent financial or non-financial conducted by management in the form of misstatement financial statements material harming the investors and creditors (ACFE, 2016)[20].

According to (Rezaee, 2005)[22] Fraudulent financial statement is related to the several schemes as follows:

a. Falsification, alteration, or manipulation of material financial records, supporting documents, or business transactions;

b. Material intentional misstatement, deletion, or error presentation of events, transactions, accounts or other significant information which is a source of information on financial statement;

c. Deliberate misapplication, intentional misinterpretation, and wrongful execution of accounting standards, principles, policies and methods used to measure, recognize, and report economic events and business transactions;

d. intentional omissions and disclosures or presentation of inadequate disclosures regarding accounting standards, principles, practices, and related financial information;

e. the use of aggressive accounting techniques through illegitimate earnings management;

f. Manipulation of accounting practices under the existing rules-based accounting standards which have become too detailed and too easy to circumvent and contain loopholes that allow companies to hide the economic substance of their performance.

Hall and Singleton (2007:296)[21] classify risk factors related to fraud in financial statements based on the classification as follows:

a. Management effects and characteristics on the controlling environment.

This factor is related to top management attitude on the internal control, management style, situational pressure, and financial statement process

b. Industrial state.

It covers the economic environment related to the regulations in which the institution is related to the operations. For instance, the companies in decline industry or whose main customers are experiencing business bankruptcy, have greater risks of fraud than the institution in stable industry.

c. Operational and finance stability characteristics.

It is related to the institution characteristics alongside the transaction complexity. For instance, companies involved in transactions with other unaudited parties are at risk of fraud.

(ACFE 2016)[20] urges that fraud in financial statement presentation can be detected through the financial statement analysis as follows:

a. Vertical Analysis, a technique to analyze the relationship among items in the income statement, balance sheet, or cash flow statement by describing them in percentages.

b. Horizontal Analysis, a technique to analyze items changing percentages on financial statement during several reports period.

c. Ratio Analysis, a tool to measure the relationship among the item values in financial statements.

\subsubsection{Days Sales in Receivables Index (DSRI)}

This ratio is used to identify the relationship of sales days in accounts receivable with net sales figures for current year compared to the previous reporting year. It is easier to determine whether the accounts receivable and income are balanced or not in two consecutive years using this ratio. The increase in sales days in accounts receivable can occur due to various reasons including changes in credit 
or financial policy, strategic change, and profit manipulation. Further, there is a possibility of income inflation if DSRI ratio has a value of more than 1 (Ugochukwu et al, 2013)[23].

\subsubsection{Gross Margin Index (GMI)}

GMI is previous year's gross margin index ratio compared to the current year. Business main purpose is increasing profit margins and reduce gross profit margins, perhaps a warning. GMI ratio with a value of more than 1 indicates a deteriorating Gross margin and becomes a sign that the company is likely to manipulate income (Ugochukwu et al, 2013)[23].

\subsubsection{Asset Quality Index (AQI)}

AQI is a ratio determining the relationship between number of current assets and non-current assets as property, plant and equipment for running year total assets with the previous year. According to Siegel (1991)[24], if AQI is greater than 1, it indicates that the company has the potential to increase its involvement by charging costs. In addition, this ratio evaluates the asset quality among the two years. Then, asset realization risk increasing and asset quality reducing become an indicator to detect profit manipulation.

\subsubsection{Sales Growth Index (SGI)}

SGI is the ratio of current year's net sales compared to the previous year. The increasing of company growth becomes an indicator of profit manipulation. However, developing companies depend on external finance than mature. Financial sources need might increase managers to manipulate whether profits and sales or achieve future targets and benefits (Wahlen, J.M., Baginski, S.P., \& Bradshaw, 2015 : 465)[25]. If it has a value of more than 1 or smaller than 1 , there is a possibility that a company is under pressure and might manipulate profits to maintain performance (Ugochukwu et al, 2013)[23].

\subsubsection{Depreciation Index (DEPI)}

Depi is a ratio of depreciation from the previous year compared to the current year. In the case of a ratio is greater than 1 , the company has implemented a policy to expand the depreciation rate by extending depreciation to increase profits (Wahlen, J.M., Baginski, S.P., \& Bradshaw, 2015 : 465)[25]. Depi ratio with a value is greater than 1 indicates the Asset Trend is depreciated at a slower rate to increase income (Ugochukwu et al, 2013)[23].

\subsubsection{Profit Sharing Ratio}

Najib and Rini (2019)[12] in his research "Analysis of Fraud Affecting Factors in Sharia Banks" indicates that Sharia Compliance proxied by the profit sharing ratio has a significant negative effect on fraud in the Bank. This result means when the value of Profit Sharing Ratio is higher, the number of occurring fraud is lower.

\section{Research Method}

The type of research is descriptive research describing the characteristics of a phenomenon that can be used as a basis for making decisions to solve business problems. The data used were secondary data. The data taken were data from Sharia Rural Banks (BPRS) HA Financial Statements in 2013, 2014, 2015 (the last 3 years before being liquidated).

The data collection technique in this research used documentation method. This research used Ratio Index analysis technique for financial statements data to be classified as non-manipulator or manipulator categories. It was classified as manipulator if M Score was greater than -2.22. On the other hand, it was classified as Non-Manipulator if M Score smaller than -2.22. M Score was calculated based on the equation below:

M Score $=-6,65+0,823 * \mathrm{DSRI}+0,906 * \mathrm{GMI}+0,593 * \mathrm{AQI}+0,717 * \mathrm{SGI}+0,107 * \mathrm{DEPI}$

\section{Result \& Discussion}

\subsection{Background of Sharia Rural Bank (BPRS) Ha}

PT Sharia Rural Bank HA (BPRS HA) in Indonesia. In the website of Deposit Insurance Corporation (Lembaga Penjamin Simpanan - LPS), the business license of Sharia Rural Bank (BPRS) $\mathrm{HA}$ has been revoked based on Board of Commissioners of the Financial Services Authority number 
KEP-X/D.0X/X01X on XX April XX01X. Tempo (2016)[26] revealed that the Financial Services Authority has revoked the business license of Sharia Rural Bank(BPRS) HA due to fraud in the management resulting in the financial performance did not meet the standard. In addition, the news also reported that Capital Adequacy Ratio (CAR) was minus of $205.61 \%$ and Non Performing Financing (NPF) reached 88.97 percent or Rp 13.71 billion from the total financing of Rp 19.8 billion.

\subsection{Sharia Rural Banks (BPRS) Classification (Manipulator / Non Manipulator)}

By applying beneish ratio approach, it can be seen that BPRS HA is indicated as manipulator or non-manipulator, namely by calculating M-Score. If $\mathrm{M}$ Score is greater than -2.22 , it is indicated as Manipulator. While, if M Score smaller than -2.22 , it is indicated as Non-Manipulator. Below is the data needed to calculate M Score:

Table 1. Data Input of Beneish ratio

\begin{tabular}{|l|r|r|r|}
\hline \multicolumn{1}{|c|}{ Data Input } & \multicolumn{1}{c|}{$\mathbf{2 0 1 5}$} & \multicolumn{1}{c|}{$\mathbf{2 0 1 4}$} & \multicolumn{1}{c|}{$\mathbf{2 0 1 3}$} \\
\hline Total net receivables & $13,103,975$ & $18,330,794$ & $15,903,568$ \\
\hline Total current assets & $15,306,057$ & $21,997,056$ & $19,298,486$ \\
\hline Net fixed assets & 237,952 & 310,269 & 383,817 \\
\hline Total Assets & $17,102,765$ & $22,809,335$ & $20,180,866$ \\
\hline Depreciation Expenses & 72,317 & 51,320 & 104,733 \\
\hline Total amount of Debt & $25,410,559$ & $21,113,971$ & $18,741,158$ \\
\hline Total Income & $3,831,149$ & $4,670,502$ & $4,447,787$ \\
\hline Total Cost of Revenue & $2,196,026$ & $1,994,817$ & $1,446,137$ \\
\hline
\end{tabular}
found:

Based on input data as described in table 1 and the $\mathrm{M}$ Score equation, the results below are

Table 2. Results of M Score Equation:

\begin{tabular}{|c|c|c|c|}
\hline Beneish Ratio & 2015 & 2014 & 2013 \\
\hline DSRI & 0.871 & 1.098 & 1.125 \\
\hline GMI & 0.146 & 0.102 & 0.043 \\
\hline AQI & 0.927 & 1.014 & 1.034 \\
\hline SGI & 0.82 & 1.05 & 1.21 \\
\hline DEPI & 0.61 & 1.51 & 2.05 \\
\hline M Score & $(4.598)$ & $(4.138)$ & $(3.987)$ \\
\hline Manipulator (> -2.22) & - & - & - \\
\hline Non-Manipulator $(<-2.22)$ & $\mathrm{V}$ & $\mathrm{V}$ & $\mathrm{V}$ \\
\hline
\end{tabular}

Based on table 2, it was found that BPRS HA in 2013, 2014, and 2015 are classified as nonmanipulator. It indicates that BPRS HA in those years did not perform financial statements fraud.

\subsection{Analysis of Beneish Ratio and Syariah Compliance Ratio}

\subsubsection{Change Analysis of DSRI since 2013 - 2015}

DSRI is used to measure accounts receivable and balanced income or not in two consecutive years. If the increase in the number of days of sales in accounts receivable means the impact of changes in credit policies to spur sales. If DSRI ratio has value more than 1 , then it has possibility of income inflation (Ugochukwu et al, 2013)[23]). From table 2, it can be seen that in 2013 and 2014, the DSRI ratio was 
above 1, indicating the existence of income manipulation. However, the DSRI ratio was below 1 in 2015 , indicating that the management did not perform income manipulation. In addition, it can also be seen that DSRI Ratio continued to decline every year, indicating that BPRS HA tended to minimize its income manipulation towards the year of revoking business license. Based on the data above, it shows that the management was indicated to perform income manipulation. However, approaching in 2016, the management's tendency to perform the manipulation declined along with the improvement in the CAR ratio in 2014, from 9\% to $12 \%$ and the DSRI Ratio in 2014 from 1,125 to 1,098. Nevertheless, in 2015 , the DSRI Ratio which did not indicate income manipulation seesaw 0,871 , but contrary to the deteriorating CAR ratio of minus $63 \%$.

\subsubsection{Change Analysis of GMI since 2013 - 2015}

The increases GMI indicates that the company is inflating profits. If GMI ratio has a value of more than 1 , then it has possibility of deteriorating Gross margin that indicates the company is more likely to manipulate income (Ugochukwu et al, 2013)[23]). From table 2, it can be seen that GMI Ratio was not above 1, indicating that BPRS HA was not inflating the profit.

\subsubsection{Change Analysis of AQI since 2013 - 2015}

According to Siegel (1991)[24], if AQI is greater than 1, it shows that the company has the potential to increase its involvement by suspending the cost. From table 2, it can be seen that AQI ratio was above 1 in 2013 and 2014, indicating the existence of manipulation by suspending the cost. However, in 2015, AQI ratio was below 1, indicating that the management did not perform suspension of costs. In addition, it can also be seen that AQI ratio continued to decline every year, indicating that BPRS HA tended to minimize the suspension of cost toward 2016 (revocation of business license). Based on the data above, it shows that the management was indicated to perform manipulation by performing suspension of cost. However, the management's tendency to manipulate declined along with the improvement in the CAR ratio in 2014, from 9\% to 12\% and the AQI Ratio in 2014 from 1.034 to 1.014. Nevertheless, in 2015 , the AQI ratio of 0.927 which did not indicate manipulation was contrary to the deteriorating CAR ratio of minus $63 \%$.

\subsubsection{Change Analysis of SGI since 2013 - 2015}

SGI can show which company includes fake sales. The increase in SGI shows that there is a tendency for companies to record fictitious income to consider the normal growth expected in that period. If SGI ratio has a value of more than 1 or too smaller than 1 , then it has a possibility that a company under pressure might manipulate profits to maintain performance (Ugochukwu et al, 2013)[23]. Form table 2, it can be seen that SGI ratio was above 1 in 2013 and 2014, indicating the existence of profits manipulation. However, SGI ratio was below 1 in 2015, indicating that the management was not manipulating the profits. In addition, it can also be seen that the SGI ratio continued to decline every year, indicating that BPRS HA tended to minimize manipulating profits. Based on the data above, it can be seen that the management was indicated to perform profits manipulation. However, the management's tendency to perform manipulation declined along with the improvement in the CAR ratio in 2014, from $9 \%$ to $12 \%$ and the SGI Ratio in 2014 from 1.21 to 1.05 . Nevertheless, in 2015, the SGI Ratio of 0.82 which did not indicate manipulation was contrary to the deteriorating CAR ratio of minus $63 \%$.

\subsubsection{Change Analysis of DEPI since 2013 - 2015}

If the DEPI is greater than 1 (one), it indicates that the rate of depreciating assets is slowing, which increases the possibility that the company has raised estimates of assets useful lives or applied a new method of increasing income. Beneish (1999)[4] estimated that there is a positive relationship between DEPI and the possibility of manipulation. From table 2, it can be seen that the DEPI ratio was above 1 in 2013 and 2014, showing the existing of depreciation manipulation indications. However, the DEPI ratio is below the number 1 in 2015 , indicating that the management was not indicated to manipulate depreciation. In addition, it can also be seen that the DEPI ratio continued to decline every year, indicating that BPRS HA tended to minimize manipulating depreciation toward 2016 (revocation of business licenses). Based on the data above, it shows that management was indicated to perform depreciation manipulation. However, over time, the manipulation tendency declined along with the 
improvement in the CAR ratio in 2014, from 9\% to $12 \%$ and the DEPI Ratio in 2014 from 2.05 to 1.51. Nevertheless, in 2015, the DEPI ratio of 0.61 which did not indicate manipulation was contrary to the deteriorating CAR ratio of minus $63 \%$.

\subsubsection{Change Analysis of Profit Sharia Ratio}

Table 3. Data Input of Sharia Compliance

\begin{tabular}{|c|c|c|c|}
\hline Data Input & $\mathbf{2 0 1 5}$ & $\mathbf{2 0 1 4}$ & $\mathbf{2 0 1 3}$ \\
\hline Mudharobah Financing & $10,005,500$ & $9,282,000$ & $6,354,000$ \\
\hline Musyarokah Financing & 83,700 & 83,700 & 83,700 \\
\hline Total Financing & $20,437,563$ & $18,696,545$ & $16,268,203$ \\
\hline
\end{tabular}

Based on input data as described in table 3, the results of the profit-sharing ratio are found below:

Table 4. Sharia Compliance

\begin{tabular}{|c|c|c|c|}
\hline Sharia Compliance & 2015 & 2014 & 2013 \\
\hline Profit Sharing Ratio & 0.494 & 0.501 & 0.396 \\
\hline
\end{tabular}

Based on table 4, the results show that BPRS HA in 2013 had a low Profit-Sharing Ratio, which means that the implementation of BPRS HA towards low sharia compliance would have an indication of great fraud. The profit-sharing ratio in 2014 increased, which means that the BPRS HA reduced the indication of fraud in Islamic banks. In 2015, BPRS HA had a decline in the profit-sharing ratio, showing an indication of fraud that had increased.

Based on other information in the BPRS HA Publication report, that the Capital Adequacy Ratio (CAR) as of 31 December 2015, 2014 and 2013 were respectively (-63\%), 12\%, 9\%. This ratio is used to measure the ability of banks to provide funds for business development purposes and to accommodate the risk of possible losses caused by bank operations. On the strength of CAR as of December 31, 2015 and within 180 days, the management of BPRS HA was unable to recover CAR, so finally the Financial Services Authority decided to liquidate. A significant decrease in CAR was due in 2015 to the allowance for possible losses on earning assets of Rp 6,964,537,000, which increased significantly compared to the

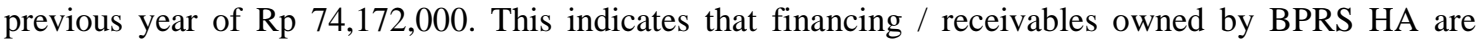
problematic.

\section{Conclusions, Implication, and Limitation \\ 5.1 Conclusion}

Based on the discussion above, the conclusions are as follows:

1. The classification of BPRS HA during 2013 to 2015 based on beneish ratios revealed that BPRS HA was classified as a non-manipulator in those years.

2. It was only 4 of the five banish ratios used in this research, namely DSRI, AQI, SGI, and DEPI, indicating that BPRS HA tended to manipulate financial statements in 2013 and 2014.

3. In 2015, BPRS HA experienced a decline in the profit-sharing ratio, showing an indication of increased fraud.

\subsubsection{Implication}

Ratio that can prove the existing of fraud in BPRS HA can be used to detect fraudulent financial statements.

\subsubsection{Limitation}

In this research, we only used 5 Boenish Ratios and Profit-Sharing Ratio to analyze fraud occurred in BPRS HA due to limited data in the BPRS HA financial statements. 


\section{References}

[1]Liputan 6 : 2023, Halal industry and Islamic finance is accomplished USD 6,8 Triliun. www.Liputan6.Com. Retrieved August 27, 2019 (https://www.liputan6.com/bisnis/read/3805946/2023industri-halal-dan-keuangan-syariah capai-usd-68-triliun) (2018)

[2]Liputan 6 : Fiktious credit case, 3 Mandiri Syariah Bank received Rp 9 M. www.Liputan6.Com. Retrieved July 12, 2019 (https:/www.liputan6.com/news/read/737695/kasus-kredit-fiktif-3-pejabat-banksyariah mandiri-terima-rp-9-m) (2013)

[3]Finansial Bisnis : Fraud the main reason BPR was liquidated. Www.Finansial.Bisnis.Com. Retrieved July 27, 2019 (https://finansial.bisnis.com/read/20150211/90/401671/javascript) (2015)

[4]Beneish, Messod D : The detection of earnings manipulation. Financial Analysts Journal (1999)

[5]Kaur, Raghuveer, Kartikay Sharma, and Ashu Khanna : Detecting earnings management in India: A sector-wise study.” European Journal of Business and ManagementOnline) (2014)

[6]Roxas, Maria L : Financial statement fraud detection using ratio and digital analysis. Journal of Leadership, Accountability and Ethics (2011)

[7]Tarjo and Nurul Herawati : Application of Beneish M-Score models and data mining to detect financial fraud. Procedia - Social and Behavioral Sciences (2015)

[8]Omar, Normah, Ridzuan Kunji Koya, Zuraidah Mohd Sanusi, and Nur Aima Shafie : Financial statement fraud: A case examination using Beneish model and ratio analysis. International Journal of Trade, Economics and Finance (2014)

[9]Suyanto : Fraudulent financial statement: evidence from statement on auditing standard no. 99. Gadjah Mada International Journal of Business (2009)

[10]Handayani, Tarjo, and Rimawati, Yuni : Correlation of financial statement components in detecting financial fraud. Asia Pacific Fraud Journal (2016)

[11]Rahman, R. Abdul and I. S. Khair Anwar : Types of fraud among Islamic Banks in Malaysia. International Journal of Trade, Economics and Finance (2014)

[12]Najib, Haifa and Rini Rini. 2019. "Sharia compliance, Islamic corporate governance and fraud in Syariah Bank.” JURNAL AKUNTANSI DAN KEUANGAN ISLAM (2019)

[13]Apriliani Astuti, M., R. Dewi Y Rozali, and A. Cakhyaneu : Prevention of fraud in Sharia Banking [14]Junita, Nuur : Detection of Syariah Banking financial statemnet fraud in fraud triangle theory perspective (2016)

[15]Suryanto, Tulus and Ridwansyah Ridwansyah : The Shariah financial accounting standards: how they prevent fraud in Islamic Banking. European Research Studies Journal (2016)

[16]Fathi, Wan Nor Iffah Wan Mohd, Erlane K. Ghani, Jamaliah Said, and Evita Puspitasari : Potential

[17]Kompas : BPR is prone to being liquidated because of fraud. Www.Ekonomi.Kompas.Com. Retrieved July 27, 2019 (https://ekonomi.kompas.com/read/2017/09/14/161500126/bpr-rawan-dilikuidasi-karenamasalah-fraud-) (2017)

[18]Usnah, Siti Asmaul and Noven Suprayogi: Students look Economics and Business Faculty Airlangga University about Sharia compliance in Syariah Bank ing." Jestt (2015)

[19]Sutedi, Andrian : Syariah Banking: Review and Some legal aspects. Bogor: Ghalia Indonesia (2009) 